\title{
災害時要援護者の階段上昇避難支援に関する実験的研究 背負い・簡易担架・車いすによる階段上昇搬送比較 \\ EXPERIMENTAL STUDY ON STAIR ASCENT TRANSPORTATION FOR VULNERABLE PEOPLE
}

Comparison by types of transportation; giving a piggyback ride, carrying a handy stretcher and carrying a wheelchair

李 知 香*, 北後明彦**, 西野智研***

Jihyang LEE, Akihiko HOKUGO and Tomoaki NISHINO

\begin{abstract}
This study is aiming to compare stair ascent transportation speed and physical burden of evacuation supporters according to the types of stair ascent transportation for vulnerable people experimentally. In this study, we measured heart rate of the supporters to indicate physical burden during the transportation. The subjects of this experiment were male students, age of 18-24. Experimental conditions were the ways of stair transportation and the weight of vulnerable people. The types of stair transportation were giving a piggyback ride, carrying a handy stretcher and carrying a wheelchair. Each experimental trial was video-recorded for measurement of ascent speed and observing supporters movement. As a result, this research proves that the weight of vulnerable people has an impact on the ascent speed and physical burden of supporter and giving a piggyback ride is the fastest in all ways of stair ascent transportation but the physical burden for a supporter is the heaviest.
\end{abstract}

Keywords : vulnerable people, stair ascent transportation, transport speed, physical burden, evacuation supporter 要援護者, 階段上昇搬送, 搬送速度, 身体負荷, 避難支援者

\section{1. はじめに}

2011 年に起こった東日本大震災以降、津波が陸上に氾濫する事態 に備え津波に耐えうる一定の高さを持った構造物を、一時的な避難 空間 (以下、津波避難ビルと呼ぶ) として利用することの重要性が指 摘されている。特に、自力での避難が困難な災害時要援護者を搬送 する避難支援者にとって、内部での階段上昇は、避難支援方法や身 体負担によって、避難に比較的長い時間を伴う事態が懸念される。 このことから、予想される津波来襲までの時間内に津波避難ビルへ 避難する要援護者に対する階段上昇支援方法による搬送所要時間や 避難支援者への負荷などについて、予め検討しておく必要がある。

これまでにも、津波避難を想定した階段上昇に関する研究はなさ れてきた。これらは、自力での階段上昇が可能な被験者を対象に、 避難者が単独で上昇する場合 ${ }^{1)}$ と一定の群集密度下で上昇する場合 の歩行実験 2) から、歩行速度といった避難時間推定に必要な基礎資 料を得ている。階段での災害時要援護者の避難支援者（介助者）に よる搬送を想定した研究 ${ }^{3)}$ もなれているが、これは階段降下によ る車椅子利用者の下階搬送の有効性を検討した実験である。災害時 要援護者の階段上昇搬送については、病院における津波を想定した 避難訓練時に実測した研究 $\left.{ }^{4}\right)$ があるが、限られた条件で行われたも のである。
そこで本研究は、実験的方法で、要援護者の体重を統制した上で、 階段上昇搬送の方法別に階段上昇搬送速度を明らかとするとともに、 身体負荷を心拍数測定により把握することとした。

階段上昇の方法については、上記の病院の避難訓練で使われたも のと同じタイプの簡易担架と車い寸を使用した階段上昇搬送ととと もに、東日本大震災当時の要援護者の津波避難ビルへの階段上昇搬 送に実際に用いられた背負い搬送注 1)を取り上げた。

\section{2. 災害時要援護者の階段上昇搬送実験}

\section{1 搬送実験の実施場所と被験者}

本実験は 2013 年 12 月から 2014 年 5 月にかけて行った。その中 で、実験を行った日の気温は最高気温 $19.0^{\circ} \mathrm{C}$ 、最低気温 $3.6^{\circ} \mathrm{C}$ であ り、搬送結果に影響を与える可能性がある暑さはなかった。実験は 神戸大学工学部スタジオ棟の室内階段で実施した。図 1 に実験に使 用した階段の形状を示す。

この実験の被験者はアルバイトで雇用した 18 歳-24歳の男子学生 68 名（避難支援者役 64 人、要援護者役 4 人）である。避難支援者 役の被験者は、1つの試行の夕実施している。要援護者役の被験者 は、繰り返し実験に参加している。

被験者の服装は普段着、足元は普段履きなれた靴を装着して行っ
$*$ 神戸大学大学院工学研究科 博士後期課程 $\cdot$ 工修

***神戸大学都市安全研究センター 教授・学博

*** 独立行政法人建築研究所 研究員・博士 (工学
Graduate Student, Graduate School of Engineering, Kobe Univ., M. Eng.

Prof., Research Center for Urban Safety and Security, Kobe Univ., Ph. D. Research Engineer, Building Research Institute, Dr. Eng. 
た。全ての被験者の健康状態は良好で、実験に影響する身体的な障 害はなかった。

本実験は要援護者を階段上昇搬送する際の速度を求めることを目 的としているため、要援護者役の動きは実際の要援護者搬送の状況 と変わらないように再現した。背負い搬送の場合、要援護者役は避 難支援者につかまるような行動は取らずに、図 4-(a)のように支援 者が要援護者の手を握るように教示した。簡易担架の場合は、自力 歩行はできるが、歩行速度が遅く階段歩行が困難な要援護者を搬送 する状況を考えて避難開始合図の後、要援護者役は床に敷かれた簡 易担架に横たわるように教示した。車い寸搬送の場合、車い寸利用 者が車い寸に乗ったまま津波避難ビルに到着し、そのまま上階に搬 送する状況を考えて搬送開始するようにした。
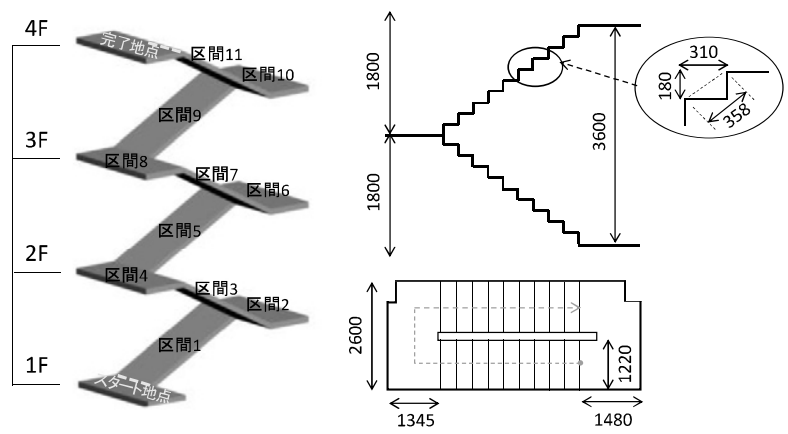

図 1 実験に使用した階段の形状（単位：mm）

\section{2 搬送方法と実験手順}

\section{2.1 搬送方法と要援護者役の体重の設定}

背負いや簡易担架、車い寸による搬送において、搬送位置やつ かみ方などの搬送方法が搬送速度に影響を与える可能性がある ので、事前に教示により搬送方法を統一した。各搬送方法の教示 内容は以下の通りである。

[背負い搬送］要援護者役を背負い、膝の下から腕を入れて 両膝を抱え込んでください。その時、背中の高い位置で背負 い、要援護者役の両腕を平行にさせて両手をしっかり持って 搬送してください。

[簡易担架搬送］ 3 人の搬送者が 1 組となり、災害時要援護 者役 1 名を搬送することを基本としてください。まず、担架 を床に敷いておき、安全ベルトを要援護者役に装着してくだ さい。その後、ショルダーベルトを避難支援者の肩にかけ、 持ち手は手を下から入れて、脚を包み込んでください。要援 護者の頭の方にいる人は前方を向いて持ち手を握ってくだ さい。その後、要援護者役の頭を進行方側にして、そのまま 階段を上がってください。

[車い寸搬送］4 人の搬送者が 1 組となり、災害時要援護者 役 1 名を搬送することを基本とし、車いすを囲むようにして 左右に 2 人ずつ立ってください。前側の搬送者はレッグレス トとアームレスト、後ろ側搬送者はハンドグリップ、ハンド リムを握り、搬送してください。

この実験では、要援護者搬送時、支援者が受ける影響を把握する ため、要援護者役の体重を重いケースと軽いケースを設定した。 $\mathrm{e}^{-}$ stat 総務省統計局の平成 23 年度体力・運動能力調查データを基
に、重いケースは、65 歳以上の男性平均体重 $62.04 \mathrm{~kg}$ を重いケー ス、65 歳以上の女性の平均体重 $51.25 \mathrm{~kg}$ を軽いケースとした。これ らに見合った体重の被験者を割り当て、細かくは重りで調整した。

実験に用いた車いすの重さは $17.9 \mathrm{~kg}$ であり、詳細な寸法は図 2 の通りである。また、簡易布製担架の重さは $1.7 \mathrm{~kg}$ 、寸法は幅 $68 \mathrm{~cm}$ 、全長 $190 \mathrm{~cm}$ である。

表 1 各搬送用具のサイズと重さ

\begin{tabular}{c|c|c}
\hline 区分 & サイズ & 重さ \\
\hline 車椅子 & 図 $2(\mathrm{a})$ 記載の通り & $17.9 \mathrm{~kg}$ \\
\hline 簡易担架 (布製) & 幅 $68 \times$ 全長 $190 \mathrm{~cm}$ & $1.7 \mathrm{~kg}$ \\
\hline
\end{tabular}

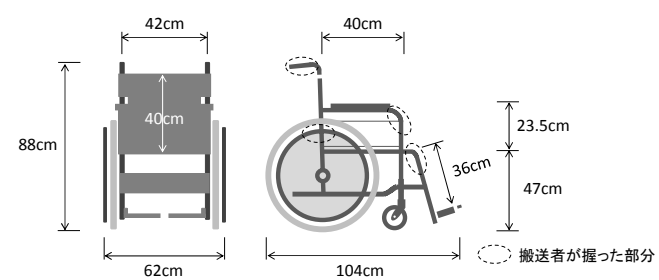

（a）車椅子

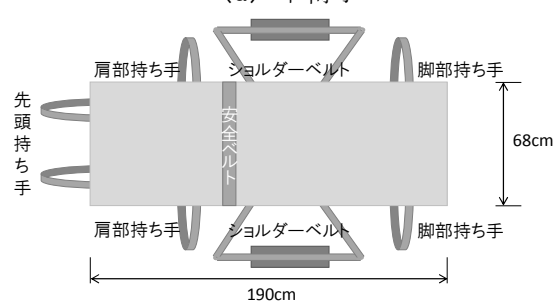

（b）布製簡易担架

図 2 搬送用具の寸法

\section{2.2 実験手順}

実験は背負い搬送、簡易担架搬送、車い寸搬送の 3 種類であり、 それぞれの搬送方法の試行は、次の手順に従って実施した。

(1)要援護者階段搬送時の心拍変化を把握するため、心拍計を、支 援者役の被験者に装着した。

(2)搬送の仕方を統一寸るため、搬送方法別に避難支援法を前述の 通り教示した。

(3)被験者に想定させる実験状況を統一寸るため、東日本大震災当 時の津波映像を 5 分間見せ、「このような津波に備え、要援護 者を運んでください」と教示した。

(4)被験者は搬送開始の合図で、要援護者役を持ち上げた。

(5) 4 階まで搬送を行った。この時、被験者に「可能な限り、速め の速度で要援護者を運んでください」と教示した。

(6) 4 階に要援護者を降ろした時点から 1 分 30 秒が経過した時点 で、再び手順(4)-(5)を繰り返した。

(7)手順(4)-(5)を 2 回終えた後、「残り、2 回ありますが、無理なく 続けられますか。『はい』か『いいえ』で答えてください」と被 験者に質問した。

８被験者の明確な「はい」の意思表示がない限り実験を終了した。 (9)被験者が、明確に「はい」と答えた場合に限り、もう一度手順 (4)-(5)を行った。この時、実際の反復搬送は 3 回目で終了とし たが、被験者の安全のため残り 2 回あると教示した。もう一度、 搬送を続けた被験者は 4 階に到着後、そこで実験を終了した。 


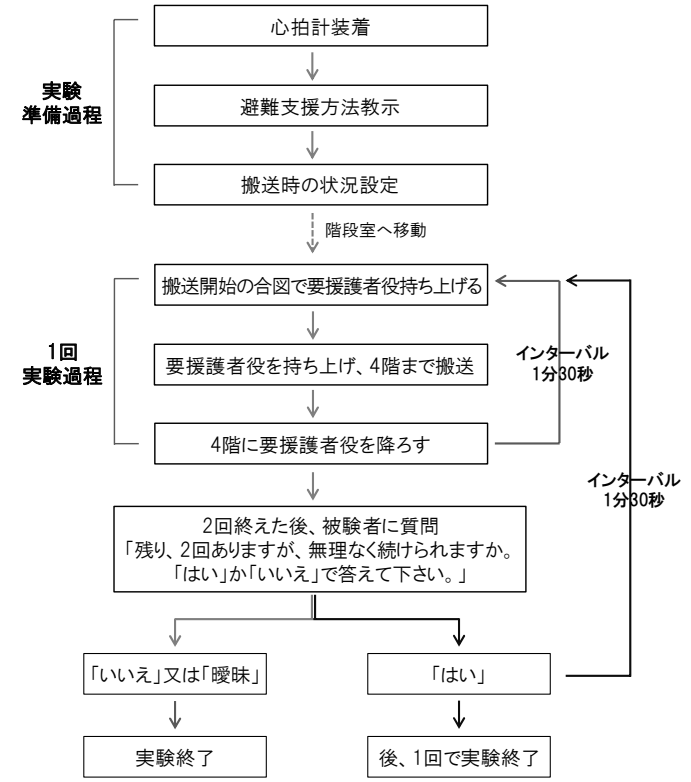

図 3 搬送実験の手順

\section{2.3 試行回数と各試行におけるインターバル}

(1) 試行回数

背負い搬送実験は、避難支援者役 1 人が要援護者役 1 人を背負 う。被験者は軽いケース 5 人、重いケース 5 人の計 10 人とした。

簡易担架搬送は、避難支援者 3 人がチームとなって、要援護者 役 1 人を搬送する。軽いケース 5 チーム、重いケース 5 チームの 計 10 チームの試行を行った。車い寸搬送は、避難支援者 4 人が チームとなって要援護者役 1 人を搬送した。軽いケース 3 チー ム、重いケース 3 チームの合計 6 チームの試行を行った。

\section{( 2 ）インターバルの適用}

インターバルは 1 階から 4 階まで搬送完了後、要援護者役を降 ろした時点から 1 分 30 秒を適用する。1 分 30 秒のインターバル の間に 1 階へ戻り、アンケートを実施するとともに休息を取る。

この時、インターバルが適用された時点からできるだけ可能な 速めの速度で 1 階に戻るように教示した。4 階から 1 階へ戻るの にかかった平均所要時間と標準偏差は $34 \pm 5.38$ 秒であり、1 階 に到着した後、休息を取る被験者に口頭でアンケートを行った。 なお、インターバル終了 10 秒前からカウントダウンし、0 秒に なると搬送開始の合図を出した。

\section{( 3 ）搬送位置}

1 階から 4 階まで 1 回目の搬送完了後、避難支援者の搬送用具 における避難支援位置別の身体負担を把握寸るため、搬送位置を 変えて、2 回目の搬送を行う。

車い寸搬送被験者は毎回搬送完了後、前後被験者の位置（搬送 方向を基準に前方 $\rightarrow$ 後方 $\rightarrow$ 前方、後方 $\rightarrow$ 前方 $\rightarrow$ 後方、図 4(b) 参 照）を変える。

簡易担架も、毎回搬送完了後、搬送位置（搬送方向を基準に先 頭 $\rightarrow$ 側面 $\rightarrow$ 側面、側面 $\rightarrow$ 先頭 $\rightarrow$ 側面、側面 $\rightarrow$ 側面 $\rightarrow$ 先頭、図 4 (c) 参照）を変えて、新たなポジションで避難支援する。

これらの条件を基に搬送実験を行った被験者の属性を表 2 に 示す。背負い搬送は被験者それぞれの属性を示しており、簡易担 架と車い寸搬送チームの属性は、搬送チーム被験者（支援者役）
の身長と体重の平均である。

図 4 に背負い搬送の仕方を統一寸るため被験者に見せたイメー ジ5)を示す。また、実験当時の搬送状況を写真 1 に示した。

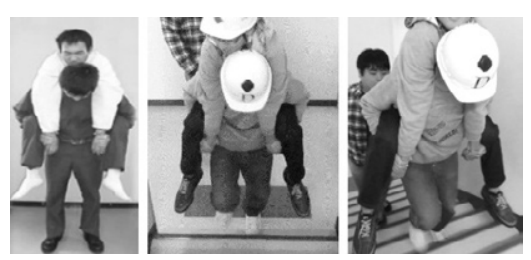

(a) 背負い搬送の仕方 ${ }^{5)}$

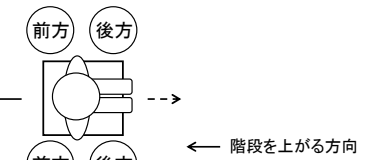

前方 後方 $\quad$ - 階段を上がる者の視界方向

(b) 車椅子の避難支援者位置

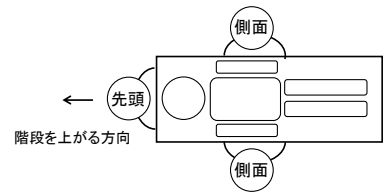

（c）簡易担架の避難支援者位置

図 4 搬送仕方及び避難支援者構成

表 2 各試行における被験者の属性（簡易担架搬送、車いす搬送の 支援者役の身長・体重は、それぞれ 3 人、4 人の平均）

\begin{tabular}{|c|c|c|c|c|c|c|}
\hline 区分 & 支援者役 & $\begin{array}{l}\text { 身長 } \\
(\mathrm{cm})\end{array}$ & $\begin{array}{l}\begin{array}{c}\text { 体重 } \\
(\mathrm{kg})\end{array} \\
\end{array}$ & \multicolumn{2}{|c|}{$\begin{array}{c}\text { 要援護者役 } \\
(\mathrm{kg})\end{array}$} & $\begin{array}{l}\text { 搬送 } \\
\text { 回数 }\end{array}$ \\
\hline \multirow{10}{*}{$\begin{array}{c}\text { 背負い } \\
\text { 搬送 }\end{array}$} & 被験者 1 & 173 & 55 & \multirow{5}{*}{$\begin{array}{l}\text { 軽い } \\
\text { ケース }\end{array}$} & 51.7 & 2 回 \\
\hline & 被験者 2 & 169 & 60 & & 52.2 & 2 回 \\
\hline & 被験者 3 & 170 & 63 & & 51.7 & 3 回 \\
\hline & 被験者 4 & 171 & 64 & & 52.0 & 3 回 \\
\hline & 被験者 5 & 173 & 70 & & 52.2 & 3 回 \\
\hline & 被験者 6 & 182 & 83 & \multirow{5}{*}{$\begin{array}{l}\text { 重い } \\
\text { ケース }\end{array}$} & 62.0 & 2 回 \\
\hline & 被験者 7 & 176 & 62 & & 65.1 & 2 回 \\
\hline & 被験者 8 & 165 & 70 & & 65.1 & 2 回 \\
\hline & 被験者 9 & 173 & 65 & & 63.9 & 2 回 \\
\hline & 被験者 10 & 175 & 60 & & 62.0 & 3 回 \\
\hline \multirow{10}{*}{$\begin{array}{c}\text { 簡易担架 } \\
\text { 搬送 }\end{array}$} & チーム 1 & 173 & 61 & \multirow{5}{*}{$\begin{array}{l}\text { 軽い } \\
\text { ケース }\end{array}$} & 51.25 & 3 回 \\
\hline & チーム 2 & 169 & 65 & & 51.25 & 3 回 \\
\hline & チーム 3 & 173 & 60 & & 51.25 & 3 回 \\
\hline & チーム 4 & 170 & 52 & & 51.25 & 3 回 \\
\hline & チーム 5 & 169 & 55 & & 51.25 & 3 回 \\
\hline & チーム 6 & 165 & 62 & \multirow{5}{*}{$\begin{array}{l}\text { 重い } \\
\text { ケース }\end{array}$} & 62.04 & 3 回 \\
\hline & チーム 7 & 174 & 62 & & 62.04 & 3 回 \\
\hline & チーム 8 & 171 & 60 & & 62.04 & 3 回 \\
\hline & チーム 9 & 165 & 52 & & 62.04 & 3 回 \\
\hline & チーム 10 & 172 & 61 & & 62.04 & 3 回 \\
\hline \multirow{6}{*}{$\begin{array}{l}\text { 車いす } \\
\text { 搬送 }\end{array}$} & チーム 1 & 173 & 60 & \multirow{3}{*}{$\begin{array}{l}\text { 軽い } \\
\text { ケース }\end{array}$} & 51.25 & 3 回 \\
\hline & チーム 2 & 171 & 54 & & 51.25 & 3 回 \\
\hline & チーム 3 & 170 & 57 & & 51.25 & 3 回 \\
\hline & チーム 4 & 169 & 64 & \multirow{3}{*}{$\begin{array}{l}\text { 重い } \\
\text { ケース }\end{array}$} & 62.04 & 3 回 \\
\hline & チーム 5 & 167 & 53 & & 62.04 & 3 回 \\
\hline & チーム 6 & 174 & 66 & & 62.04 & 3 回 \\
\hline
\end{tabular}

\section{3 測定方法}

実験過程は固定カメラによる撮影と追跡撮影により記録した。 心拍数は支援者役の被験者に心拍計を装着し、要援護者搬送時 の心拍数の変化を把握した。心拍計による心拍記録は、5 秒毎に 実験準備から実験後、教示室に戻るときまで測定し、避難支援に よる身体負荷の程度を把握した。 


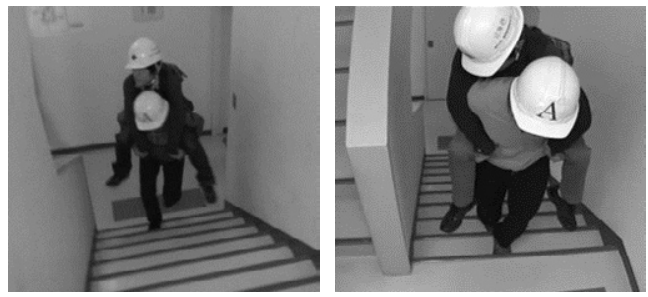

(a) 背負い搬送

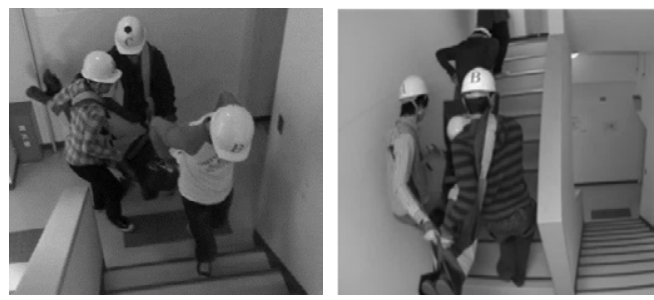

（b）簡易担架搬送

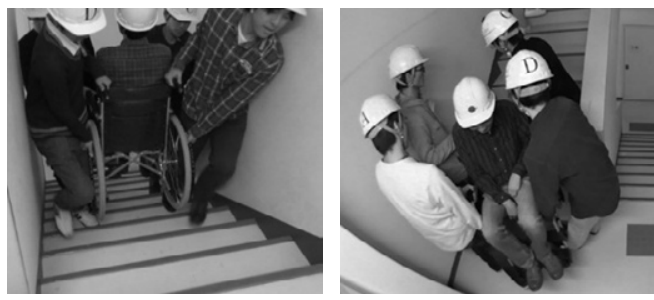

（c）車い寸搬送

写真 1 実験当時の搬送状況

また、避難支援者を対象にアンケートを実施し、避難支援者の 属性、搬送時に感じられた身体負担の程度及び実験後の身体状態 について回答を得た。

搬送所要時間は、撮影したビデオを再生して測定した。(先頭) 避難支援者が階段を上がり始める時点、踊り場に着く時点、また 階段を上がり始める時点とした。測定区間及び測定タイミングを 表 3 に示す。垂直距離は階段の垂直方向の距離（高さ）、水平距 離（踊り場）は踊り場の中心軸に沿った 3 つの動線（図 1 参照） の合計であり、測定区間は図 5 に示す。

表 3 測定区間及び測定タイミング

\begin{tabular}{|c|c|c|}
\hline 区間 & 距離 $(\mathrm{m})$ & 測定タイミング \\
\hline 区間 1 & 1.8 & 階段上がる $\rightarrow$ 踊り場に着く \\
\hline 区間 2 & 2.725 & 踊り場を曲がる \\
\hline 区間 3 & 1.8 & 階段上がる －上階に着く \\
\hline 区間 4 & 2.86 & 階の踊り場を曲がる \\
\hline 区間 5 & 1.8 & 階段上がる $\rightarrow$ 踊り場に着く \\
\hline 区間 6 & 2.725 & 踊り場を曲がる \\
\hline 区間 7 & 1.8 & 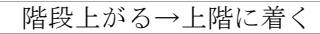 \\
\hline 区間 8 & 2.86 & 階の踊り場を曲がる \\
\hline 区間 9 & 1.8 & 階段上がる 踊り場に着く \\
\hline 区間 10 & 2.725 & 踊り場を曲がる \\
\hline 区間 11 & 1.8 & 階段上がる $\rightarrow$ 上階に着く \\
\hline
\end{tabular}

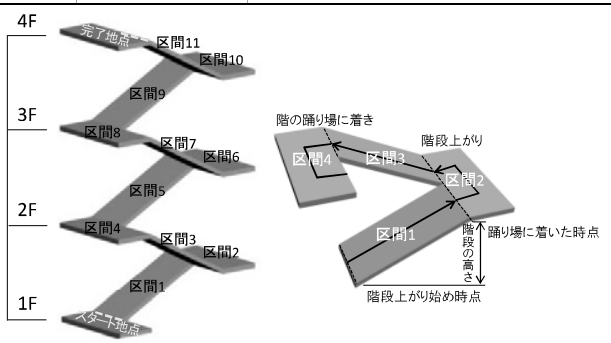

図 5 搬送所要時間の測定区間

\section{3. 実験結果}

\section{1 避難支援方法による搬送所要時間}

実験は 1 階から 4 階まで 1 試行で 3 回搬送するのが基本であ るが、被験者の安全を考慮し、2 回目の搬送完了後、被験者に実 験持続可否を尋补、3 回目の実験の実施を決定した。そのため、 簡易担架と車い寸搬送実験のすべての被験者が 3 回目まで搬送 完了したことに対し、背負い搬送の場合、3 回目まで搬送完了し た被験者の比率は軽いケースが 6 割、重いケースが 2 割であった ため、3 回目の搬送を行っていない被験者に対する 3 回目の搬送 所要時間は得られていない。

避難支援方法別の搬送所要時間を図 6 に示す。図 6 は箱ひげ図 であり、それぞれの階別搬送所要時間について、最小值、第一四 分位 (25\%点)、中央值 $(50 \%$ 点)、第三四分位 $(75 \%)$ 、最大值の $5 つ の$ 要素でデータの分布を示した。なお、搬送所要時間は要援 護者の体重の軽いケースと重いケースに区分しており、4 階ゴー ル地点までかかる所要時間を示している。

背負い搬送の場合、階別最大搬送所要時間は軽いケースで 15 秒、重いケースで 22 秒であり、簡易担架の場合、軽いケースで 19 秒、重いケースで 30 秒である。これに対し、車いすの場合、 搬送所要時間の最大值は軽いケースで 33 秒、重いケースで 64 秒 で、避難支援方法や要援護者役の体重によって搬送所要時間に大 きな差があることが分かる。なお、 1 回目、2 回目、3 回目とも、 全般的に上階一上がるほど、階別搬送所要時間が長くなる傾向に ある。

避難支援方法別の各回平均搬送時間を図 7 に示す。避難支援方 法による平均所要時間は背負い搬送の場合、軽いケースは平均 31 秒、重いケースは平均 43 秒であった。

簡易担架搬送時の所要時間が最も短いのは軽いケースの要援 護者役を搬送した試行であり、1 回の搬送に 30 秒程度の時間が かかっているのに対し、所要時間が最も長いのは重いケースで、 毎回 1 分 15 秒以上の時間がかかった。簡易担架の階段上昇搬送 時、1 回の搬送にかかる平均所要時間は軽いケース 42 秒、重い ケースで 1 分 3 秒であった。

車い寸搬送は、すべての試行において毎回 1 分以上の時間がか かった。搬送所要時間が最も短いのは軽いケースの試行であり、 1 階から 4 階までの 1 回搬送に 1 分程度の時間がかかった。これ に対し、最も所要時間が長いのは重いケースでの試行で、1 回目 の搬送時は、2 分 46 秒かかった。搬送所要時間が最も長い試行 は、他の試行と比べ、踊り場を曲がるとき、比較的時間がかかっ ており、全体的に搬送所要時間が長くなったと思われる。

車い寸搬送時、踊り場を曲がることに関する教示はせず、被験 者の判断の下で踊り場を曲がった。従って、階段を上がる際の状 態のまま、車いすを持ち上げて搬送する試行があるのに対し、踊 り場に着くと、車椅子を降ろし、車い寸を押して踊り場を曲がる 試行もあった。搬送に最も長い時間がかかった試行は、踊り場に 着いて、車い寸を降ろして押した場合であり、車いすを持ち上げ て踊り場を曲がった試行と比べ、踊り場で時間がよりかかったこ とが分かる。車い寸搬送の場合、1 回の搬送にかかる平均所要時 間は軽いケース 1 分 11 秒、重いケース 1 分 49 秒である。 


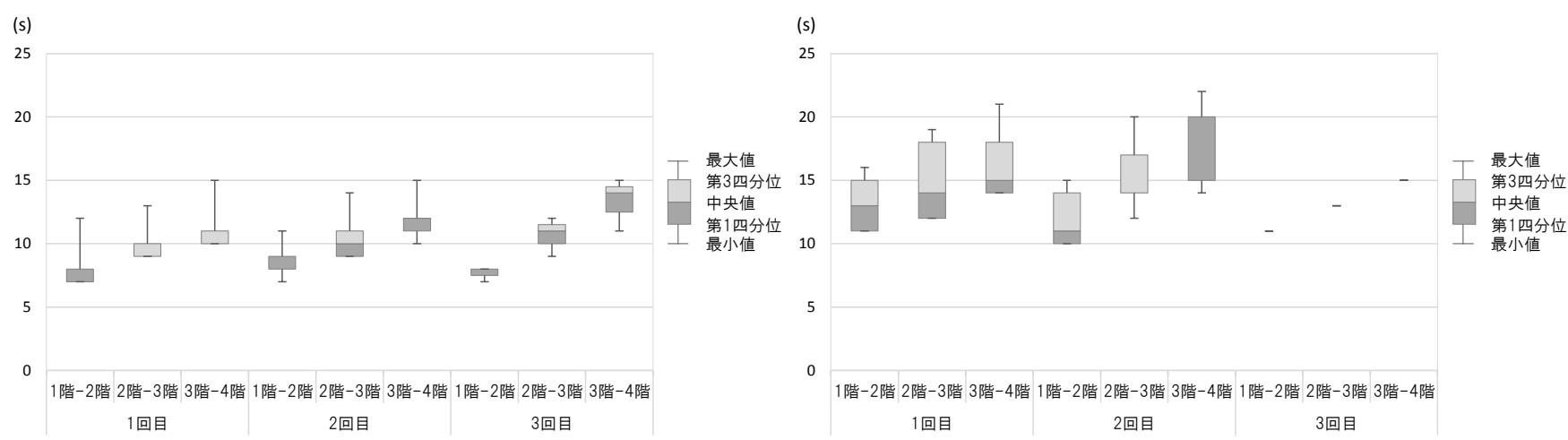

[要援護者役の体重が軽いケース］（a）背負いによる階別搬送所要時間［要援護者役の体重が重いケース］
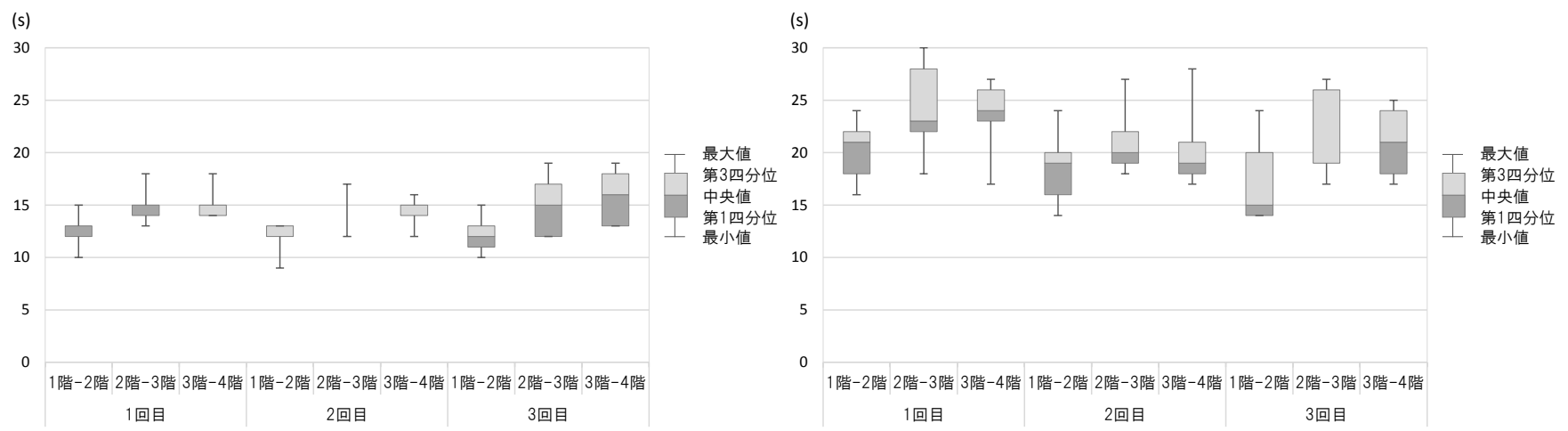

[要援護者役の体重が軽いケース］

（b）簡易担架による階別搬送所要時間［要援護者役の体重が重いケース］

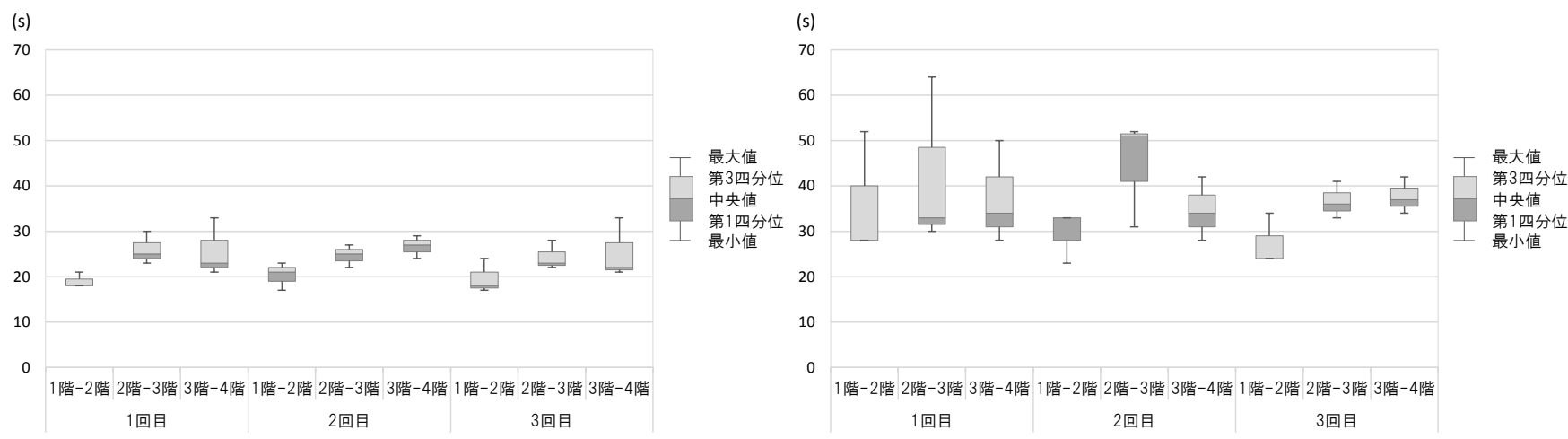

[要援護者役の体重が軽いケース］（c）車いすによる階別搬送所要時間［要援護者役の体重が重いケース］

図 6 搬送方法による階別搬送所要時間

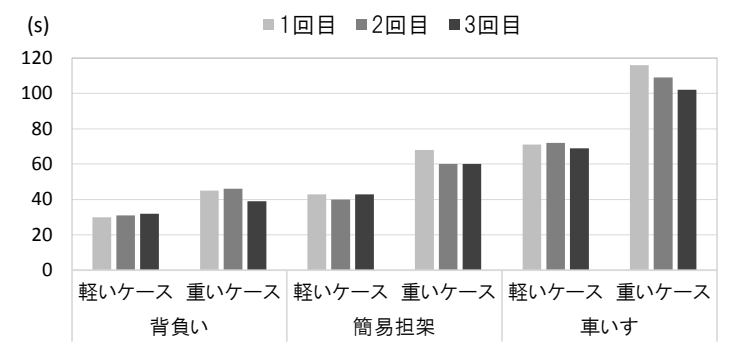

図 7 避難支援方法による平均搬送時間（垂直距離 $10.8 \mathrm{~m}$ ）

\section{2 避難支援方法による被験者心拍変化}

本実験では被験者の心拍数測定を通じ、身体に感じられる負担 の程度を把握した。搬送時の被験者心拍数変化を図 8 に示す。点 線による折れ線は要援護者役の体重が軽いケース、実線が重いケ
一スである。心拍数は搬送準備時点から 3 回の反復搬送完了時点 まで示している。搬送準備は搬送開始の合図をした時点であり、 搬送準備をして、要援護者役を持ち上げ、階段を上がり始めるま でである。簡易担架搬送の場合、搬送準備開始後、階段を上がり 始めた時点で心拍数が急に高くなったことが分かる。これは、簡 易担架搬送準備過程が背負いや車い寸搬送準備に比べ、手間のか かるためだと考えられる。簡易担架を床面に敷いて、要援護者役 を横たえた後、持ち上げて、階段を上がり始めるまでの過程で、 搬送準備時間がより必要となり、他の搬送方法に対し、搬送準備 過程で心拍数が急に上がる傾向にある。

心拍数は搬送方法や個人によって差があるが、全般的に 1 回目 の搬送時に急に上がり、インターバルの時には休息を取りながら 下がる傾向にあるが、2 回目以後、順次心拍数がより上がった。 
また、反復搬送するほど、最大心拍数に到達する傾向にある。

搬送方法別に見ると、被験者の心拍数は背負い搬送が最も高い。 3 回目の搬送後、最大心拍数に到達し、ケースによる被験者の最 大心拍数は重いケースで 192、軽いケース 162 である。これは、 他の避難支援者に比べて高く、背負い搬送時被験者に最も大きな 身体負担となっていることが分かる。これに対し、簡易担架や車 い寸搬送は要援護者の体重を 3 人又は 4 人の被験者で分担する
ので、相対的に身体的な負担は少ないと考えられる。

簡易担架と車い寸搬送の場合、それぞれの被験者によって心拍 数に大きな差があるが、簡易担架搬送時の平均心拍数は要援護者 役の体重に関係なく、重いケースと軽いケースで似ていることが 分かる。一方、車椅子搬送の場合、重い体重の要援護者役を搬送 した被験者の平均心拍数がより高くなっており、車椅子の重さが 加わった場合により要援護者役の体重が影響したと考えられる。

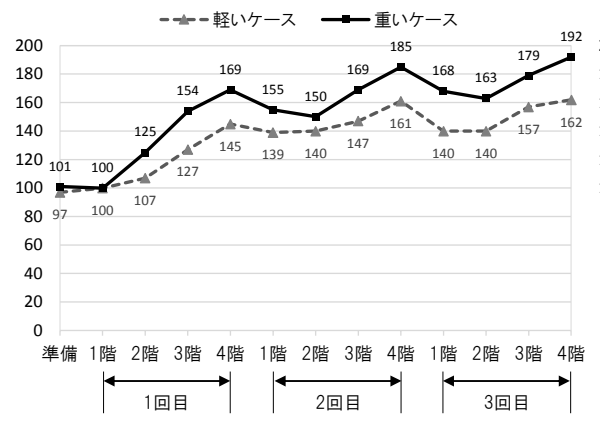

（a）背負い搬送時の被験者心拍数

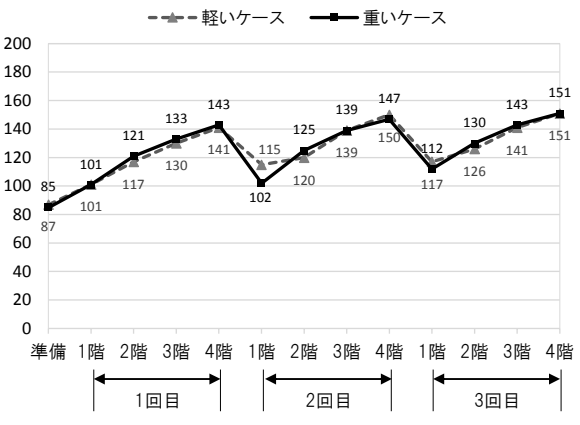

（b）簡易担架搬送時の被験者心拍数 図 8 搬送方法別被験者心拍数

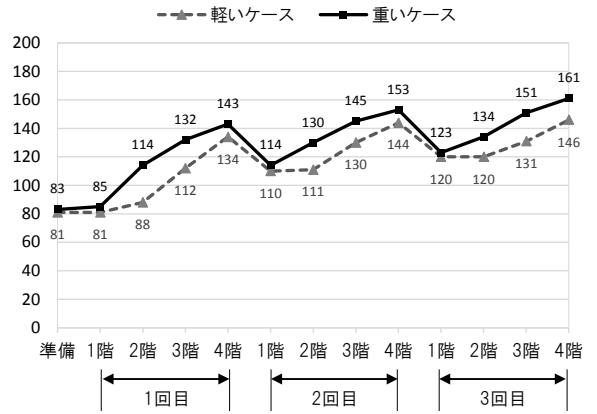

（c）車いす搬送時の被験者心拍数

\section{3 搬送方法による垂直搬送速度}

搬送方法別に被験者が階段を上がる垂直搬送速度を算定し、搬 送回数別・区間別 (図 1 参照) 上昇搬送速度グラフを図 9 に示寸。 図 9 の区間別平均速度は、点線による折れ線が要援護者役の体重 が軽いケース、実線が重いケースである。

出発地点である区間 1 の平均速度と到着地点である区間 11 の 平均速度を比べて見ると、背負い搬送の場合、いずれの場合も上 階部の速度が落ちることが分かる。これに対し、簡易担架の場合 重いケース搬送時は上階へ上がるほど搬送速度が高くなること が分かる。なお、車い寸搬送の重いケースも 1 回目、2 回目の場 合、区間 1 より区間 11 での平均速度が速くなったことが分かる。

1 階から4階まで全区間を通した平均搬送速度の繰り返し試行 による変化を表 4 に示す。

\section{表 4 平均搬送速度の繰り返し試行による変化}

\begin{tabular}{|c|c|c|c|c|}
\hline \multicolumn{2}{|c|}{ 区分 } & 1 回目 & 2 回目 & 3 回目 \\
\hline \multirow{2}{*}{$\begin{array}{c}\text { 背負い } \\
\text { 搬送 }\end{array}$} & 軽いケース & $0.53 \mathrm{~m} / \mathrm{s}$ & $0.48 \mathrm{~m} / \mathrm{s}$ & $0.48 \mathrm{~m} / \mathrm{s}$ \\
\hline & 重いケース & $0.35 \mathrm{~m} / \mathrm{s}$ & $0.35 \mathrm{~m} / \mathrm{s}$ & $0.38 \mathrm{~m} / \mathrm{s}$ \\
\hline \multirow{2}{*}{$\begin{array}{c}\text { 簡易担架 } \\
\text { 搬送 }\end{array}$} & 軽いケース & $0.40 \mathrm{~m} / \mathrm{s}$ & $0.41 \mathrm{~m} / \mathrm{s}$ & $0.39 \mathrm{~m} / \mathrm{s}$ \\
\hline & 重いケース & $0.25 \mathrm{~m} / \mathrm{s}$ & $0.29 \mathrm{~m} / \mathrm{s}$ & $0.29 \mathrm{~m} / \mathrm{s}$ \\
\hline \multirow{2}{*}{$\begin{array}{c}\text { 車いす } \\
\text { 搬送 }\end{array}$} & 軽いケース & $0.23 \mathrm{~m} / \mathrm{s}$ & $0.22 \mathrm{~m} / \mathrm{s}$ & $0.25 \mathrm{~m} / \mathrm{s}$ \\
\hline & 重いケース & $0.16 \mathrm{~m} / \mathrm{s}$ & $0.19 \mathrm{~m} / \mathrm{s}$ & $0.20 \mathrm{~m} / \mathrm{s}$ \\
\hline
\end{tabular}

背負い搬送の重いケースの場合、1 回目、2 回目の平均速度は $0.35 \mathrm{~m} / \mathrm{s}$ で、3 回目は $0.38 \mathrm{~m} / \mathrm{s}$ で速度が速くなっているが、これ は重いケースの要援護者を 3 回目まで搬送した被験者が 1 名し かおらず、また被験者の体力やコンディションによって搬送速度 に影響があるものと考えられる。

背負い搬送の軽いケースは、2 回目以降、搬送速度が低下して いるのに対し、簡易担架搬送、車い寸搬送の軽いケースでは速度 は低下せずほぼ一定である。これは、後者の搬送は、背負い搬送
に比べて身体負担が低いことによると考えられる。

簡易担架搬送、車い寸搬送の重いケース場合は、全般的には回 を重ねるほど搬送速度が上昇する傾向にある。これは反復搬送す ることにより、搬送そのものに慣れて重いことによる操作の難し さが解消されてスムーズな動きとなることと、基本的に身体負担 が背負い搬送に比べて低いことによると考えられる。

\section{4. 避難支援者へのアンケート結果}

\section{1 アンケートの概要}

アンケートは実験に参加した被験者を対象に実施し、アンケー トの概要及び構成を表 5 に示す。1 8 歳-24 歳の男子学生 64 人 (要 援護者役除外）を対象にしており、背負い搬送の被験者 10 人、 簡易担架搬送の被験者 30 人、車い寸搬送の被験者 24 人である。

アンケートは、区間別・行動別に感じられた身体負担の程度、 搬送完了後の身体状態など 3 つの項目で構成されている。

表 5 アンケート調査の概要

\begin{tabular}{|c|c|c|}
\hline & 查対象 & 実験に参加した被験者全員（64 人回答） \\
\hline \multirow{4}{*}{ 構成 } & 被験者属性 & 年齢、体重、身長、訓練時の役割 \\
\hline & \multirow{3}{*}{$\begin{array}{c}\text { アンケート } \\
\text { 項目 }\end{array}$} & 区間別、感じられた身体負担 \\
\hline & & 行動別、感じられた身体負担 \\
\hline & & 搬送実験した後、身体の状態（複数回答） \\
\hline
\end{tabular}

\section{2 搬送方法による区間別、感じられた身体負担}

\subsection{1 背負い搬送による区間別身体負担}

背負い搬送の場合、1 回目より 2 回目の搬送時、1-2 階より $3-$ 4 階での搬送時に、感じられた身体負担がきつくなった傾向にあ る。また、要援護者役の体重によって感じられる身体負担の程度 に差があり、重い体重の要援護者役を搬送した避難支援者から 「ややきつい」「きつい」という意見がより多いことが分かる。 要援護者役の体重による身体負担を図 10 に示す。 
- 要援護者役の体重が軽いケース

--・ 軽いケースの平均速度

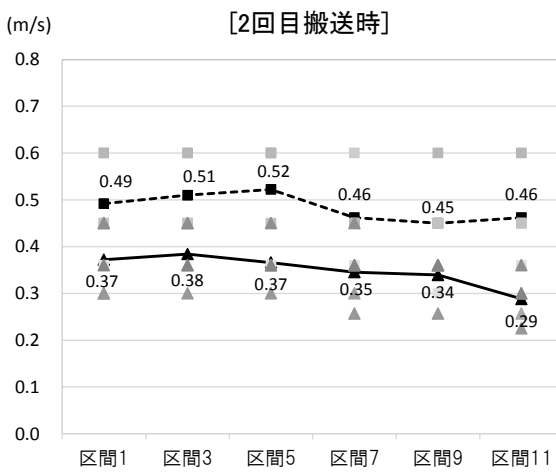

（a）背負いによる上昇搬送速度
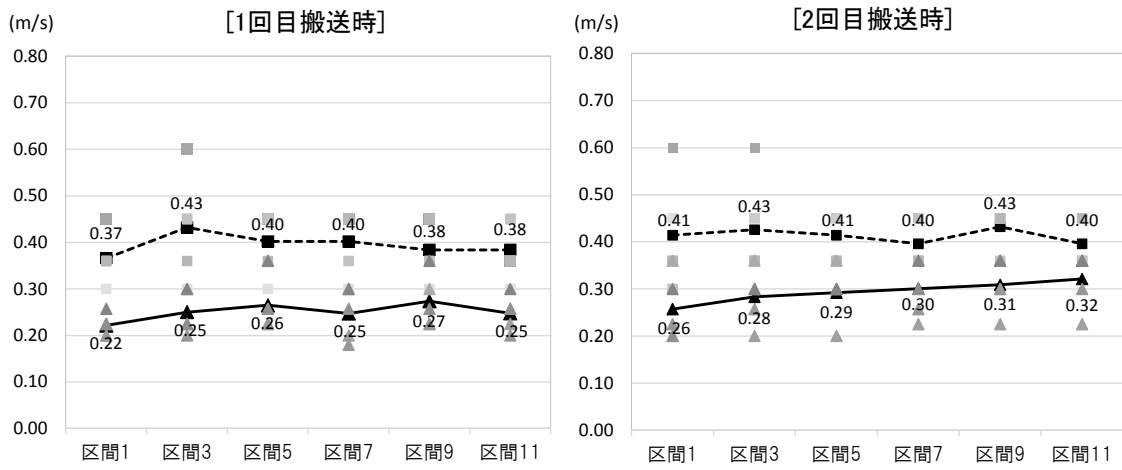

（b）簡易担架による上昇搬送速度

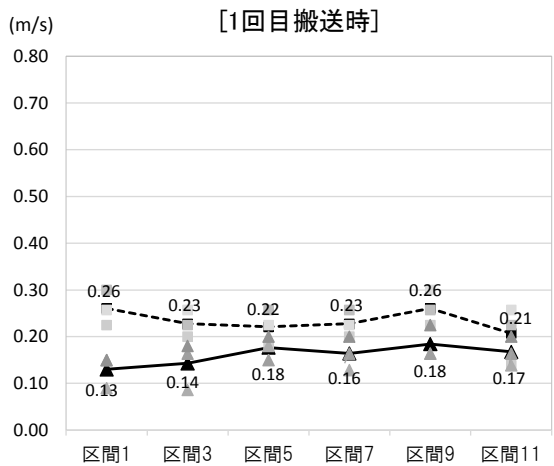

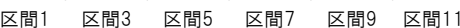

$\Delta$ 要援護者役の体重が重いケース 一 重いケースの平均速度
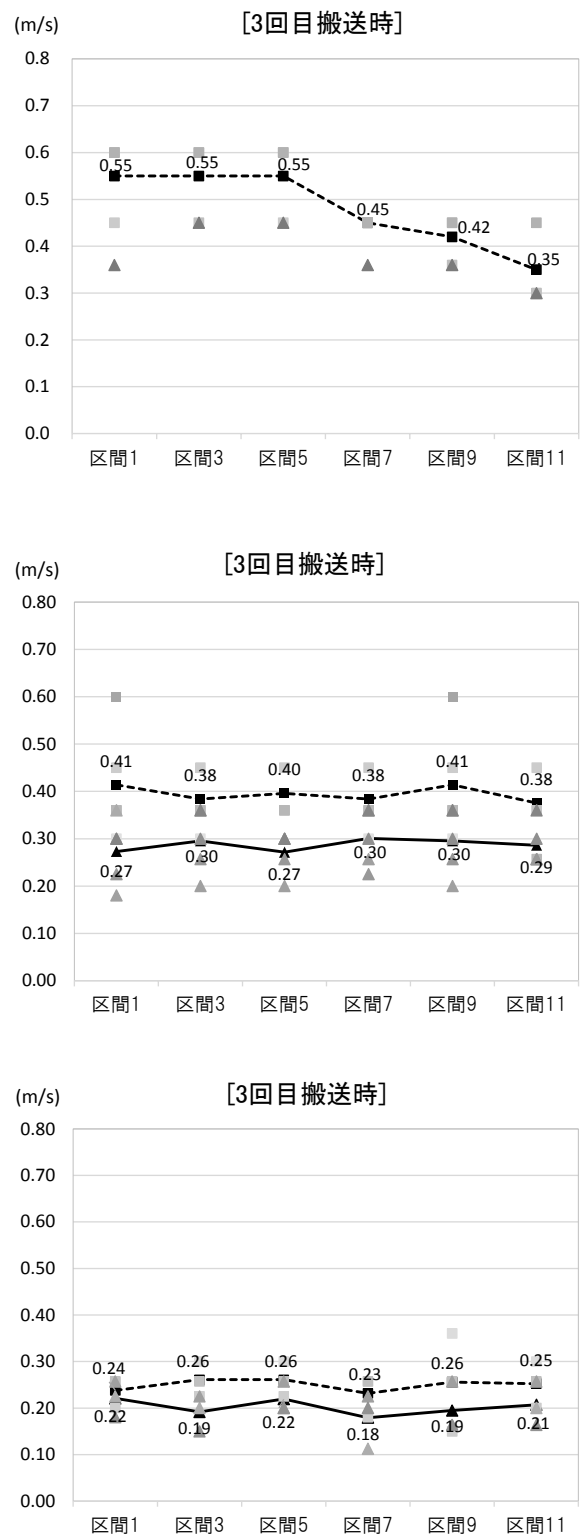

（c）車いすによる上昇搬送速度

図 9 搬送方法別上昇搬送速度

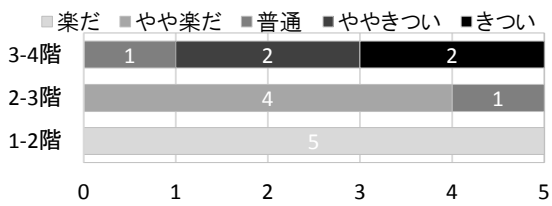

（a）軽いケースの 1 回目搬送時

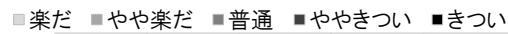

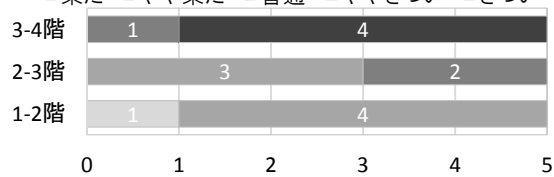

（a）重いケースの 1 回目搬送時

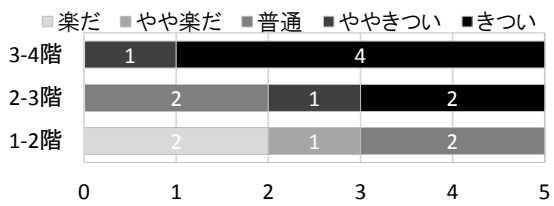

（b）軽いケースの 2 回目搬送時

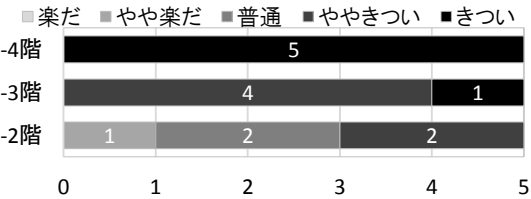

(b) 重いケースの 2 回目搬送時

図 10 背負い搬送による区間別身体負担
ロ楽だロやや楽だ 回普通 ロややきつい ・きつい

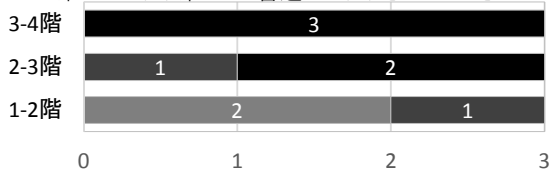

（c）軽いケースの3 回目搬送時 回楽だ、やや楽だ、普通』ややきつい 』きつい

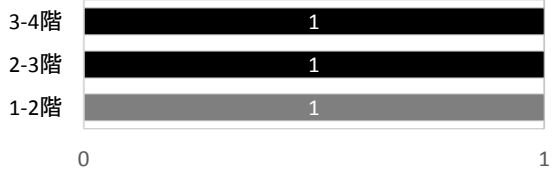

（c）重いケースの 3 回目搬送時 


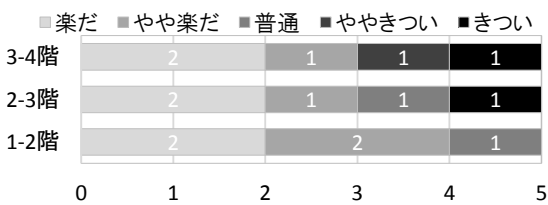

（a）軽いケースの 1 回目搬送時

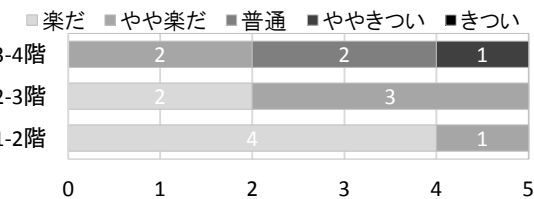

（a）重いケースの 1 回目搬送時

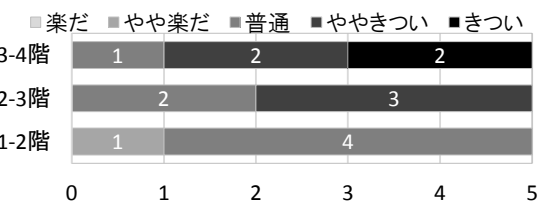

(b) 軽いケースの 2 回目搬送時

ロ楽だ ロやや楽だ ロ普通 ロややきつい』きつい

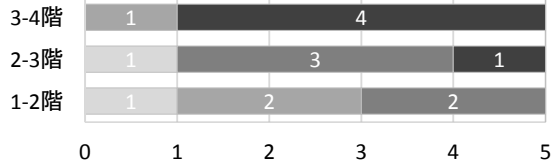

(b) 重いケースの 2 回目搬送時

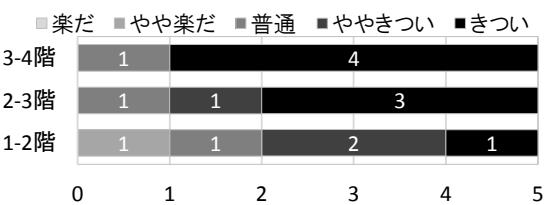

(c) 軽いケースの 3 回目搬送時

ロ楽だ ロやや楽だ ロ普通 ロややきつい ロきつ

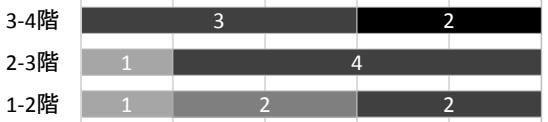

(c) 重いケースの 3 回目搬送時

図 11-1 先頭一側面一側面の位置における簡易担架による区間別身体負担

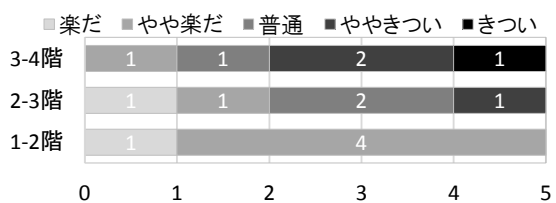

（a）軽いケースの 1 回目搬送時
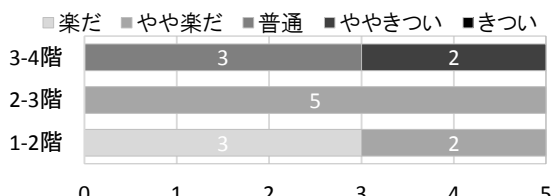

（a）重いケースの 1 回目搬送時

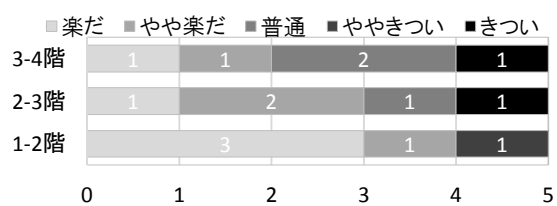

（b）軽いケースの 2 回目搬送時

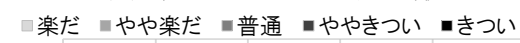

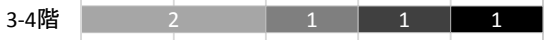

\begin{tabular}{|l|l|l|l|}
\hline $2-3$ 階 & 3 & 1 & 1 \\
\hline
\end{tabular}

1-2階

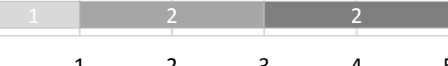

（b）重いケースの 2 回目搬送時

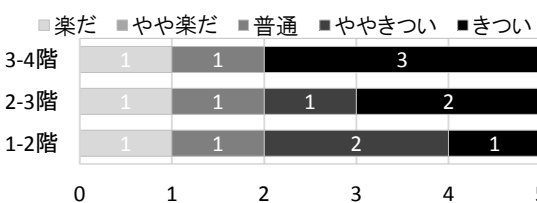

（c）軽いケースの 3 回目搬送時

回楽だ、やや楽だ 回普通 ロややきつい ロきつい

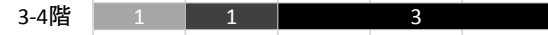

2-3階

1-2階

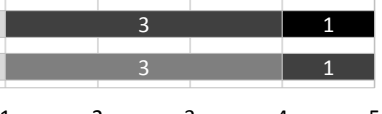

（c）重いケースの3 回目搬送時

図 11-2 側面 先頭一側面の位置における簡易担架による区間別身体負担

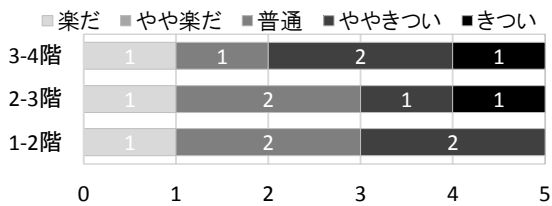

（a）軽いケースの 1 回目搬送時

ロ楽だロやや楽だ ロ普通』ややきつい』きつい \begin{tabular}{|l|l|l|l|l|}
\hline $3-4$ 階 & 1 & 1 & 2 & 1 \\
\hline
\end{tabular}

2-3階 1-2階

（a）重いケースの 1 回目搬送時

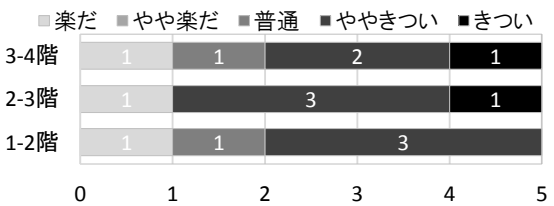

（b）軽いケースの 2 回目搬送時

ロ楽だロやや楽だロ普通』ややきつい』きつい
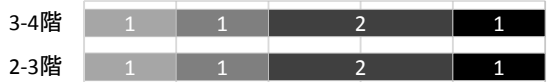

1-2階

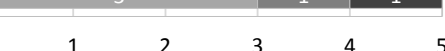

（b）重いケースの 2 回目搬送時

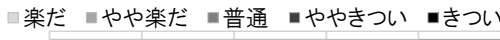
3-4階 \begin{tabular}{|l|l|l|l|}
\hline 2-3 階 & 3 & 1 & 1 \\
\hline
\end{tabular} \begin{tabular}{|l|l|l|l|}
\hline $1-2$ 階 & 3 & 1 & 1 \\
\hline
\end{tabular}

（c）軽いケースの 3 回目搬送時

回楽だロやや楽だ、普通、ややきつい 【きつい 3-4階 $\quad 2$ 2 112

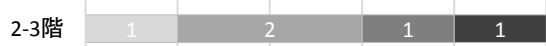
1-2階 $\quad 2 \quad 2 \quad 1$

（c）重いケースの 3 回目搬送時

図 11-3 側面 $\rightarrow$ 側面 $\rightarrow$ 先頭の位置における簡易担架による区間別身体負担

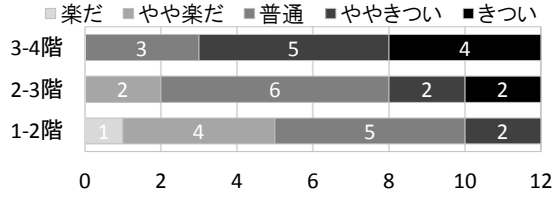

(a) 軽いケースの 1 回目搬送時

ロ楽だロやや楽だ 回普通』ややきついロきつい

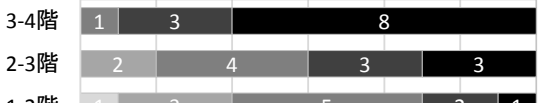

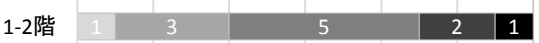

(a) 重いケースの 1 回目搬送時

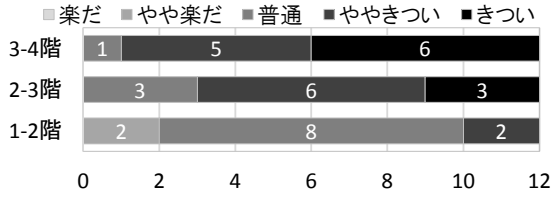

(b) 軽いケースの 2 回目搬送時

ロ楽だロやや楽だ ロ普通 ロややきつい』きつ 3-4階 1 \begin{tabular}{|l|l|l|l|l|l|}
\hline $2-3$ 階 & 2 & 1 & 4 & 5 \\
\hline
\end{tabular} \begin{tabular}{|l|l|l|l|l|}
\hline $1-2$ 階 & 3 & 3 & 4 & 2 \\
\hline
\end{tabular}

（b）重いケースの 2 回目搬送時

図 12 車いす搬送による区間別身体負担

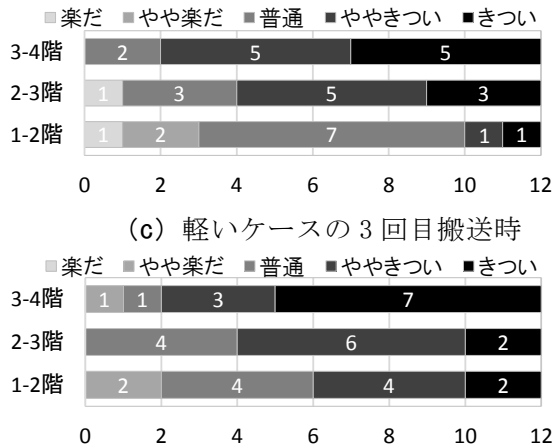

（c）重いケースの 3 回目搬送時 


\subsection{2 簡易担架搬送による区間別身体負担}

簡易担架による搬送は要援護者の体重に影響を受けるより搬 送位置によって感じられる身体負担により差がある傾向にある。

搬送位置による身体負担の程度を図 11 に示す。先頭 $\rightarrow$ 側面 $\rightarrow$ 側面の位置で搬送した被験者は、階段を上がるほど、反復搬送す るほど、順次的に身体負担を感じたことが分かる。側面 $\rightarrow$ 先頭 $\rightarrow$ 側面の順番で搬送した被験者の場合、2 回目の搬送に関わらず、 先頭の位置では 1 回目搬送時と同程度の身体負担が感じたこと が分かる。側面 $\rightarrow$ 側面 $\rightarrow$ 先頭の順番で搬送した被験者は 1 回目よ り 2 回目の反復搬送時身体負担がより感じた傾向にあり、3 回目 の反復搬送に関わらず、先頭の位置で搬送した場合、感じられる 身体負担が少ないことが分かる。

3 回の搬送をした後、被験者全員に同一な条件で、これから、 何回搬送できるかと思うか尋ねた。その結果、要援護者の体重に 関係せず、その後、2-3 回はできるという回答が得られた。アン ケートでは、反復搬送するほじ、「ややきつい」、「きつい」とい う回答が挙げられているが、このような回答を通じ、搬送そのも ので身体的な限界に到達したことではないと思われる。

\section{2.3 車いす搬送による区間別身体負担}

車い寸搬送時、感じられる身体負担は要援護者役の体重より被 験者個人の体力による傾向にある。車い寸搬送の場合、毎回搬送 後、被験者が搬送用具の前後で搬送位置を変わって実験を行った が、搬送位置に応じて身体負担を感じるより、上階ほど、また反 復搬送をするほど身体負担を感じたことが分かる。

要援護者役の体重別にみた身体負担を図 12 に示す。

\section{3 搬送方法別、各行動時に感じた身体負担}

搬送方法別に、各行動時感じた身体負担に差があるが、背負い 搬送、簡易担架搬送、車い寸搬送時、何れの場合も階段を上がる 時に「きつい」という意見が挙げられている。搬送による身体負 担を図 13 に示す。背負い搬送の場合、要援護者 1 人に対して、 避難支援者 1 人であり、階段を上がるのが最も「きつい」という 回答が挙げられているのに対し、踊り場を曲がることは負担が少 ない傾向が見られる。これに対し、簡易担架と車い寸搬送の場合、 踊り場を曲がる時、背負い搬送と比べ、より負担を感じる傾向に ある。これは、担架と車い寸は要援護者を中心に両サイドに避難 支援者が位置するため、狭い踊り場を曲がる際に取り回しが困難 であるからだと思われる。

\section{4 搬送方法別、実験後の身体状態}

搬送方法別にみた搬送後の身体状態に関するアンケート結果 を図 14 に示す。

背負い搬送の場合、6 割の被験者が「ひどい疲労感がある」と 回答しており、この比率は他の搬送方法より非常に高いことが分 かる。要援護者役の体重を他の避難支援者と分担寸る担架や車い すに対し、背負い搬送は 1 人の避難支援者が要援護者役の体重を 負担するので、他の避難支援方法より疲労感が高いことが分かる。

背負い搬送被験者からその他の意見としては、「足に力が入ら なくなる」という意見があった。

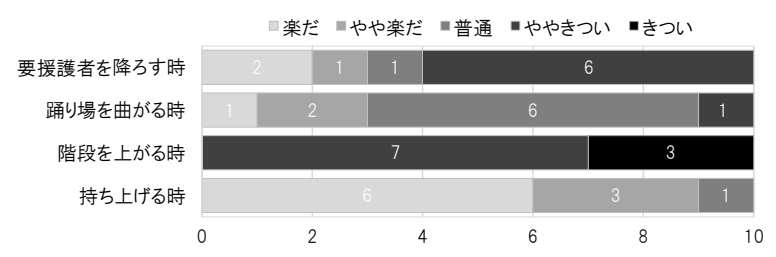

（a）背負い搬送

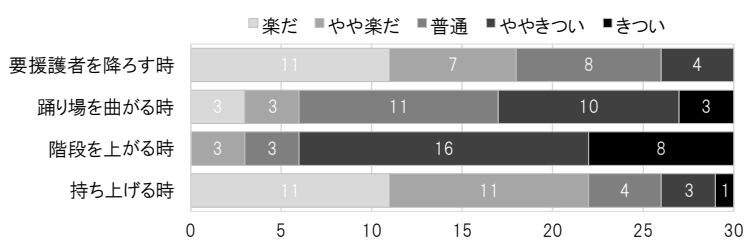

(b) 簡易担架搬送

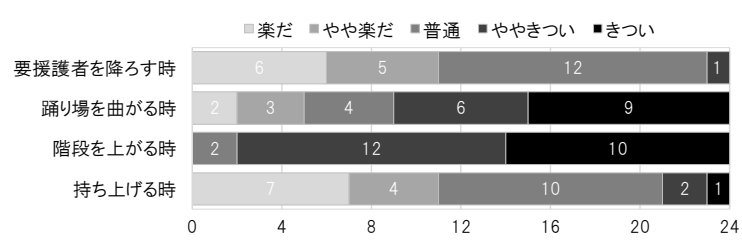

(c) 車いす搬送

図 13 搬送方法別・各行動時の身体負担

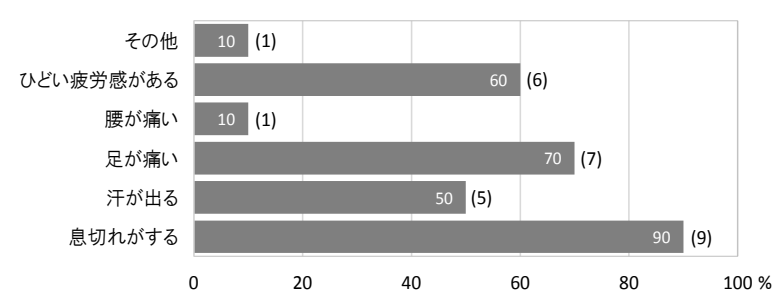

（a）背負い搬送

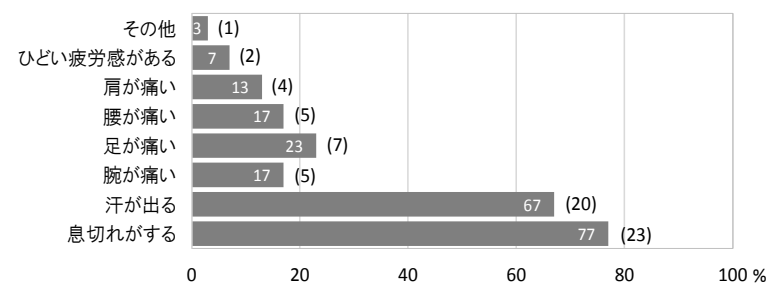

（b）簡易担架搬送

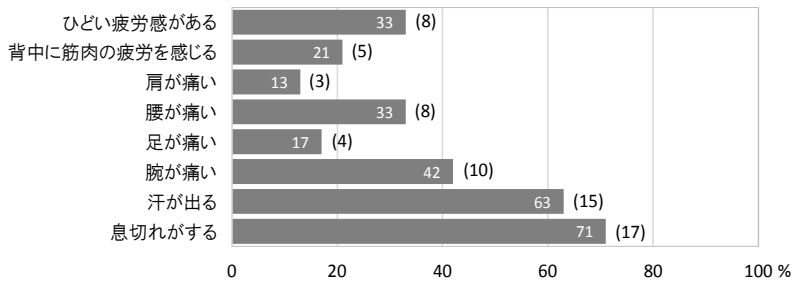

(c) 車い寸搬送

図 14 階段上昇搬送実験後の身体状態

簡易担架搬送の場合、「腕が痛い」、「腰が痛い」、「肩が痛い」 という回答が多く得られた。担架搬送時、両サイドの避難支援者 がショルダーベルトを肩にかけ、要援護者の肩と脚部の持ち手を 握って搬送したため、「腕が痛い」、「肩が痛い」という意見が多 いと思われる。また、担架の場合は他の避難支援方法とは違い、 要援護者を持ち上げる時、身体全体で担ぐように充分、腰を落と してまっすぐ、なるべく垂直に立ち上がるので、「腰が痛い」と いう意見があると考えられる。 
担架搬送後の身体状態に対するその他の意見では、「特にない」 という意見があって、簡易担架による搬送時、感じた身体負荷が 比較的少ないと思われる。

車い寸搬送の場合、「腕が痛い」、「腰が痛い」、「ひどい疲労感 がある」、「背中に筋肉の疲労を感じる」という意見が挙げられて いる。車い寸搬送時、腰を落としてそれぞれの部分を握って搬送 し、狭い踊り場を曲がる等の体勢が崩れた場合に、「腰が痛い」、 「腕が痛い」という状況となり、また、握った部分（レッグレス ト、アームレスト、ハンドグリップ、ハンドリム）の高さが約 $50 \mathrm{~cm}-90 \mathrm{~cm}$ （図 2 参照）と低く、そのため「背中に筋肉の疲労を 感じる」という状況となったと考えられる。

\section{5. 搬送方法別にみた垂直搬送速度の比較}

各測定区間における背負い搬送、簡易担架、車い寸の上昇搬送 速度の平均及び標準偏差を図 15 に示す。搬送速度が最も速いの は背負い搬送の要援護者役が軽いケースであり、速度 $0.50 \mathrm{~m} / \mathrm{s}$ で あるのに対し、最も遅いのは車いすの重いケースであり、速度 $0.18 \mathrm{~m} / \mathrm{s}$ で、2.5 倍以上の速度差があることが分かる。

要援護者役の体重による垂直搬送速度は背負い搬送の場合、軽 いケース $0.50 \mathrm{~m} / \mathrm{s}$ 、重いケース $0.36 \mathrm{~m} / \mathrm{s}$ であり、簡易担架は軽 いケース $0.40 \mathrm{~m} / \mathrm{s}$ 、重いケース $0.28 \mathrm{~m} / \mathrm{s}$ である。車いす搬送速 度は軽いケース $0.24 \mathrm{~m} / \mathrm{s}$ 、重いケース $0.18 \mathrm{~m} / \mathrm{s}$ で、それぞれの 搬送方法における軽いケースの搬送速度が重いケースより 1.3 倍程速いことが分かる。

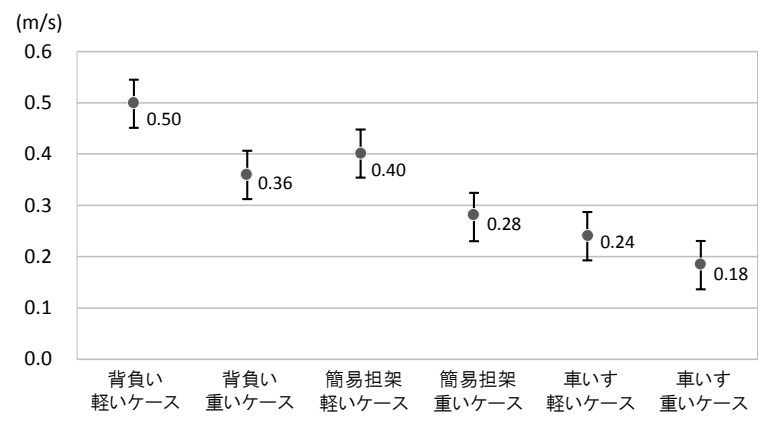

図 15 上昇搬送時の搬送方法別の平均上昇速度及び標準偏差

\section{6. まとめ}

本研究では、災害時要援護者の避難支援としての階段上昇搬送 時、搬送方法による階段搬送速度や身体負担を比較 ・分析するこ とを目的として、背負い搬送と簡易担架搬送、車い寸搬送につい てそれぞれ反復搬送実験を行った。

その結果得られた主要な点は以下の通りである。

1）避難支援方法による 1 階から 4 階まで 1 回搬送にかかる搬送 所要時間は背負い搬送の場合、軽いケースが平均 31 秒かかっ ているのに対し、重いケースは平均 43 秒である。簡易担架搬 送時の平均所要時間は軽いケース 42 秒、重いケース 1 分 3 秒 であり、車い寸搬送の平均所要時間は軽いケース 1 分 11 秒、 重いケース 1 分 49 秒であった。

2) 心拍数は、搬送方法や個人によって差があるが、全般的に 1 回 目の搬送時に急に上がり、インターバルの時には休息を取りな
がら下がる傾向にあるが、2 回目以後、順次心拍数がより上が っている。また、反復搬送するほど、最大心拍数に到達する傾 向にある。搬送方法による被験者の心拍数は背負い搬送が最も 高く、身体負担を最も感じていることが分かる。

3） 1 階から 4 階まで 3 回反復搬送時、背負いによる上昇搬送速 度は、軽いケースの平均搬送速度 $0.5 \mathrm{~m} / \mathrm{s}$ 、重いケース $0.36 \mathrm{~m} / \mathrm{s}$ 、 簡易担架搬送の場合、軽いケース $0.40 \mathrm{~m} / \mathrm{s}$ 、重いケース $0.28 \mathrm{~m} / \mathrm{s}$ 、 車い寸搬送の場合、軽いケース $0.24 \mathrm{~m} / \mathrm{s}$ 、重いケース $0.18 \mathrm{~m} / \mathrm{s}$ であり、要援護者の体重が軽いケースの方が速いことが分かる。 簡易担架搬送、車い寸搬送の場合、搬送速度は反復搬送寸るほ ど搬送に慣れて、前回の搬送ペース同様に搬送するか、より速 くなる傾向にある。

4）搬送回数別・区間別に感じられた身体負荷は上階一上がるほ ど、反復搬送するほど身体負担が感じられることが分かる。簡 易担架搬送の場合、搬送位置によって身体負担に差があり、反 復搬送に関わらず、先頭の位置で搬送する場合、感じられる身 体負担は少ないことが分かる。また、 3 回の反復搬送した後も、 その後 2-3 回搬送できるという回答があり、簡易担架搬送によ る身体負担は比較的に少ないと考えられる。

5）搬送方法別の各行動時の身体は、「階段を上がること」に最も 大きな身体負担を感じていることが分かる。背負い搬送の場合、 「階段を上がること」に最も負担を感じているが、「踊り場を 曲がること」は負担が少ないことが分かる。これに対し、簡易 担架や車い寸は「踊り場を曲がること」に負担を感じている傾 向にある。

今後、避難支援者による災害時要援護者の階段上昇搬送計画を より効果的に策定するためには、搬送速度や搬送時の身体負荷に 影響する可能性がある諸要因について検討寸る必要がある。

注

注1）気仙沼市鹿折の公民館では、東日本大震災の当日、隣接寸るデイケアセ ンターの多数の高齢者を津波からの避難のため、公民館上階一背負い搬 送したことが、2012 年 11 月に筆者らが行った公民館関係者へのヒアリ ング調査で明らかとなっている。

\section{参考文献}

1）土屋 伸一、森山修治、浜 暁也、渡邊 大地、長田 悠平、小川純子、 神 忠久、長谷見 雄二: 津波避難ビルにおける階段歩行特性に関寸る実 験研究-その1 実験概要及び階段上昇時の単独歩行特性-、日本建築学会 大会学術講演梗概集 E-1、pp. 905-906、2006.07

2）森山 修治、長田 悠平、土屋 伸一、小川 純子、浜 暁也、神 忠久、渡 邊 大地、長谷見 雄二: 津波避難ビルにおける階段歩行特性に関する実 験研究-その2 階段上昇時の群集歩行特性-、日本建築学会大会学術講演 梗概集 E-1、pp. 907-908、2006. 07

3）瀬戸口 俊也、内田 公一、山村 重行、山村 重行、布田 健、萩原一郎、 直井 英雄: 介助者による階段降下の可能性について一車い寸使用者の階 段避難の可能性に関寸る実験 その2-、日本建築学会大会学術講演梗概 集 E-1、pp. 971-972、2006. 07

4）李知香、北後明彦、西野智研、異なる避難支援者属性による車椅子と担 架を用いた階段上昇避難の比較、日本建築学会計画系論文集、No. 693、 pp. 2267-2272、2013. 11

5) http://www2.town.komono.mie.jp/secure/1006/hannsou.pdf(参照2 013.08. 10) 


\title{
EXPERIMENTAL STUDY ON STAIR ASCENT TRANSPORTATION \\ FOR VULNERABLE PEOPLE
}

Comparison by types of transportation; giving a piggyback ride, carrying a handy stretcher and carrying a wheelchair

\author{
Jihyang LEE* , Akihiko HOKUGO** and Tomoaki NISHINO*** \\ * Graduate Student, Graduate School of Engineering, Kobe Univ., M. Eng. \\ ** Prof., Research Center for Urban Safety and Security, Kobe Univ., Ph. D. \\ *** Research Engineer, Building Research Institute, Dr. Eng.
}

This study is aiming to compare stair ascent transportation speed and physical burden of evacuation supporters according to the types of stair ascent transportation for vulnerable people experimentally. In this study, we measured heart rate of the supporters to indicate physical burden during the transportation. The subjects of this experiment were male students, age of 18-24. Experimental conditions were the ways of stair transportation and the weight of vulnerable people. The types of stair transportation were giving a piggyback ride, carrying a handy stretcher and carrying a wheelchair. Each experimental trial was video-recorded for measurement of ascent speed and observing supporters movement.

As a result of the experiment, as for the ascent transportation speed by piggyback ride from the first floor to the fourth floor, the average speed of the light case is 31 seconds and for the heavy case is 43 seconds. When it comes to the average speed of stretcher transportation, the light case is 42 seconds and the heavy case is 1 minute and 3 seconds and in case of wheelchair transportation's average speed the light case is 1 minute and 11 seconds and the heavy case is 1 minute and 49 seconds.

Therefore, it was indicated that when the weight of a vulnerable people is lighter, the transportation speed is faster. The heart rates of evacuation supporters are different depending on transportation methods or individual's condition but as repetitive transportation increases, they tend to reach the maximum heart rates.

The heart rates of evacuation supporters according to transportation methods show highest was the piggyback ride so the physical burden of supporters are most felt.

There are changes of the average speed by the transportation methods and sections but in general, as transportation is higher, the transportation speed decreases.

As for the ascent transportation speed by piggyback ride, in case of repetitive transportation of 3 times from the first floor to the fourth floor, the average speed of a light case is $0.50 \mathrm{~m} / \mathrm{s}$ and for heavy case is $0.36 \mathrm{~m} / \mathrm{s}$. When it comes to the average speed of stretcher transportation, a light case is $0.40 \mathrm{~m} / \mathrm{s}$ and in heavy case is $0.28 \mathrm{~m} / \mathrm{s}$, and as for the average speed of wheelchair transportation, a light case is $0.24 \mathrm{~m} / \mathrm{s}$ and in heavy case is $0.18 \mathrm{~m} / \mathrm{s}$. Therefore, it was found that when the weight of a vulnerable people is lighter, the transportation speed is faster.

As a result, this research proves that the weight of vulnerable people has an impact on the ascent speed and physical burden of supporter and giving a piggyback ride is the fastest in all ways of stair ascent transportation but the physical burden for a supporter is the heaviest. 